\title{
Stepping from One State of Mind into a New One Drake Stutesman
}

$\mathrm{T}$ his interesting group of non-fiction pieces raises many important points about prison but, as much, they show the essential role that writing does and can play in prison life. Writing is crucial to our society, of course, but, as a teacher in prison, I found that the part it plays there has many special qualities. I teach creative writing and literature in university and in community colleges. I taught creative writing for three years in London's HMP Holloway, the largest women's prison in Europe, holding about 600 people. The median age of the prisoners was 22 years old. A few were as young as 16 . Holloway is a remand unit so the population was always in transition. Some prisoners were awaiting trial and were there for only months while others were serving very long sentences and were there for years before being rotated out.

My classes were never stable, as students could return week after week but new students could join every day, thus precluding a consistent group. The group's abilities were extremely variable. My students included women who could barely read and write and others who were highly educated; in one instance, I had a woman with a Ph.D in linguistics from a top London university. Students came to these classes for different reasons: some to learn, some to get money, meet a friend or make a contact. Many were very angry or very subdued, some were mentally ill (and should not have been in prison), and some were calm and attentive. Students could be high, frightened or bored. Though prison is often perceived as a place where one has "lots of time", therefore writing is easy, my experience was that this is not true. Prison is filled with intense distraction: it is very loud (there is much yelling), nerve wracking, enervating, depressing, and pressurizing. It also is not comfortable to open up in prison... exposing personal feelings can bring ridicule, violence or a sense of dangerous vulnerability. That anyone in prison could write anything, much less anything good, was always a phenomenon to me. But despite these volatilities, an astounding energy and a talent emerged from the restless women in the Holloway classroom.

I found that the prison students responded to class exercises in ways that I experienced nowhere else. This showed in their attitudes toward writing, in their talent, in their imagination and their need to express. I tried to teach Creative Writing as a way to experiment with words and to reveal to students what words could do. I hoped they could open to the realization that there are many ways to write down one's experiences, as opposed to 
simply writing them without understanding the power of expression itself. I put less emphasis on confessional pieces than on exercises that asked for inventive word play or exploring fun topics.

I discovered that there was a qualitative difference between prison students and students on the outside. The prisoners were more intrepid and more imaginative. In the classes outside prison, students often were insecure. They hesitated and were circumspect in taking a leap. The students at Holloway jumped in immediately and often came up with extravagant, entertaining, off beat pieces. I still remember some of their wonderful adjectives, phrases or plotlines or the cleverness of words used in a nonsense sestina or in evocative rhymes.

This is only one slice of the uniqueness of what writing does in prison. This journal's collection covers much of the breadth of writing's value there. Marilyn Buck is attentive to the nature of language itself. She wonders how we think about it, how it forms our identities, our thoughts, and how we are dominated by it. She sees the argument that language enforces class structures as especially exacerbated in prison where any kind of refusal to conform can be lethal. Jorge Antonio Renaud recognizes writing's bottom line as being a forum in which to "express frustration with prison's rigid code" and Buzz Alexander, who initiated the Prison Creative Arts Project, sees it similarly, but from a different perspective. After a series of refusals, he realized that articulating a program's worth to a director was as essential a route to getting a mandate as having a worthwhile curriculum. Judith Clark uses the essay form to examine the U.S. government's draconian cut backs to penal education in the 1990s and the disastrous effect that not having a place to express had on the system. Patricia Prewitt shows just how valuable expression is in her painful, humorous vent about the anomalous rules that a prisoner navigates even in buying from the canteen or creating something in art class. Charles Norman, Michael Rothwell and G.T. Carrillo, vividly describe the futility that prisoners often feel and how many have given up because they see no way to cope with their intense feelings.

Articulation begins all education. In prison, words act as outreach to an uninformed society, as solidarity with those who empathize, or as a route to self-acceptance. This is not atypical of writing in general and all these elements of expression, understanding, and communication are part of any teaching. But the complexities, raw feeling and potential for release from pain or release from ignorance are a hundred fold in any part of teaching, 
writing, and learning in prison. Political prisoners have often spoken of the need to write, of the solace that it gives them and how it soothes or expresses the world within a world that they inhabit in order to cope with prison, imprisonment and the prison organization. More than one prisoner has described how writing for a PEN contest or how learning to write expressively has meant stepping from one state of mind into an entirely new one. Writing, from reform proposals to a first poem, is one of prison's most vibrant, most enduring and most necessary lifelines.

\section{ABOUT THE AUTHOR}

Drake Stutesman has taught courses in literature and cinema at New York University, Montclair University, the School of Visual Arts, and the University of North London (UK). She has been a member of PEN's Prison Writing Committee since 2001 and is the Co-Chair of The Women's Film Preservation Fund. She is a novelist and the author of the cultural history Snake (Reaktion Press, 2005). Her work has been published by, among others, the British Film Institute, MoMA, Koenig Books, University of Illinois Press, Gale Press, Bookforum, and Film Quarterly. She edits Framework: the Journal of Cinema and Media. 